\title{
NURT FENOMENOLOGICZNO-EGZYSTENCJALNY W POLSKIEJ WSPÓŁCZESNEJ FILOZOFII BOGA
}

Nurt fenomenologiczno-egzystencjalny posiada w Polsce kilku znanych przedstawicieli, należą zaś do nich: M. Jaworski, J. Tischner i K. Tarnowski. Ksiądz Marian Jaworski (ur. 1926), późniejszy arcybiskup Lwowa i kardynał, był kierownikiem Katedry Fílozofii Religii w Akademii Teologii Katolickiej w Warszawie. Interesował się również problematyką filozofii Boga, nawiązując do tradycji filozofii podmiotu, zapoczątkowanej przez św. Augustyna, a kontynuowanej współcześnie przez J. Maritaina i A. Dondeyne’a. Pierwszy z nich akcentował rolę przedfilozoficznego poznania Boga, będącego rodzajem spontanicznej intuicji odkrywającej poprzez kruchość bytu obecność Boga ${ }^{1}$. Belgijski filozof, ksiądz Albert Dondeyne również mówił o przedfilozoficznym poznaniu, które nazwał „egzystencjalną fenomenologią", tj. doświadczeniem człowieka skłaniającym go do refleksji nad własnym istnieniem i jego genezą ${ }^{2}$. Dopełnieniem analizy fenomenologicznej jest refleksja metafenomenologiczna, tj. w sensie ścisłym metafizyczna. Fenomenologiczny opis rzeczywistości Dondeyne nazwał refleksją prius quoad nos, jest ona punktem wyjścia poprzez rozumowanie redukcyjne („quia”) takiego bytu, który jest prius simpliciter, tj. Boga.

M. Jaworski nawiązał do rozważań belgijskiego fenomenologa, wyróżniając filozofię bytu quoad nos i filozofię bytu jako takiego ${ }^{3}$. Odwołał się także do wypowiedzi św. Tomasza z Akwinu, które mają potwierdzać zasadność proponowanego rozróżnienia dwu typów filozofii bytu ${ }^{4}$. Filozofia bytu quoad nos to przedfilozoficzne poznanie Boga, które można nazwać fenomenologicznym opisem kondycji bytowej człowieka. „Metafizyka jako metodycznie wypracowana nie jest możliwa inaczej, jak przez nawrót do metafizyki

${ }^{1}$ Por. J. Maritain, Approches de Dieu, Paris 1953, 9-23.

2 Por. A. Dondeyne, L'experience préphilosophique et ses conditions anthropologiques de l'affirmation de Dieu, w: Existence Dieu, Tournai 1961, 147-166.

${ }^{3}$ Por. M. Jaworski, Zagadnienie reinterpretacji punktu wyjścia filozoficznego poznania Boga, w: Studia z filozofii Boga, II, Warszawa 1973, 164-191.

${ }^{4}$ Por. Thomas Aquinata, In Boethium de Trinitate lect. II, II, 1, ad 3; lect. II, I, 2. 
w człowieku" 5 . Rozgraniczenie dwojakiego typu filozofii bytu ma swe konsekwencje na terenie filozofii Boga, argumentacja uzasadniająca Jego realność jest „eksplikacją krytyczną metafizycznego wymiaru świadomości ludzkiej”6. Jaworski sądził, że punktem wyjścia argumentacji teodycealnej jest filozofia bytu quoad nos, a nie filozofia bytu jako takiego. Drogi Tomasza były wyrazem fascynacji kosmosem, współcześnie w większym stopniu przedmiotem uwagi filozofii jest sam człowiek, dlatego argumentację Akwinaty należy zreinterpretować uwzględniając bytowość człowieka: jego strukturę, dynamikę i wartości. Polski fenomenolog był przekonany, że antropologiczny punkt wyjścia argumentacji na istnienie Boga nie zmienia w sposób istotny metody zastosowanej w drogach Akwinaty, ponieważ jest to także rozumienie redukcyjno-regresywne. Tradycyjnie interpretowany tomizm (tak esencjalny, jak egzystencjalny) uzasadniał realność Boga opierając się na metafizycznej zasadzie przyczynowości. W przekonaniu Jaworskiego „św. Tomasz w swych drogach do Boga nie mówił o zastosowaniu żadnych zasad, ale wskazywał na określone stany rzeczowe, które jego zdaniem domagają się ostatecznej racji bytowej”7. Obecność Boga jest „odczytywana” w strukturze rzeczywistości, zwłaszcza w egzystencji człowieka. Metafizyczne dowody są jedynie eksplikacją prawdy o Bogu uchwyconej w przedfilozoficznej intuicji. „Teoretyczna refleksja nie może zastąpić bezpośredniej intuicji bytu, i bez tej intuicji nie odgrywa żadnej roli decydującej w doprowadzeniu człowieka do przeświadczenia o Bogu"

Jaworski nie zakwestionował dróg Akwinaty, lecz zerwał z ich interpretacją klasycznego tomizmu. Od filozofii bytu przeszedł do filozofii podmiotu, nawiązując do nurtu augustyńsko-fenomenologicznego. Proponując oparcie filozofii Boga na filozofii bytu quoad nos, dowartościował rolę personalno-aksjologicznego doświadczenia człowieka. Proponowana reinterpretacja filozoficznej refleksji nad Bogiem wynikała z przekonania, że współczesny ateizm ma źródła nie tyle epistemologiczno-metodologiczne (sensualizm), co przede wszystkim antropologiczne9 ${ }^{9}$. Ateizm marksizmu i J.P. Sartre'a jest tego potwierdzeniem. Współczesna filozofia teistyczna powinna wskazywać na ontyczne i aksjologiczne powiązanie człowieka z Bogiem.

Drugim przedstawicielem nurtu fenomenologiczno-egzystencjalnego w Polsce był ksiądz Józef Tischner (1931-2000), profesor Papieskiej Akademii Teologicznej w Krakowie, autor prac: Świat ludzkiej nadziei (Kraków 1975),

${ }^{5}$ M. Jaworski, Przedfilozoficzne i filozoficzne poznanie Boga, w: Studia z filozofii Boga, I, Warszawa 1968, 334.

6 Tamże. Autor aprobował stanowisko D. de Petera.

7 M. Jaworski, Uwagi na temat stosunku teologii naturalnej do filozofii bytu „quoad nos”, „Studia Philosophiae Christianae” 9 (1973) nr 1, 274.

8 Tenże, Przedfilozoficzne i filozoficzne poznanie Boga, s. 346.

9 Por. tenże, Idea Boga a wspótczesny ateizm, w: O Bogu dziś, Warszawa 1974, 121-132. 
Myślenie wedtug wartości (Kraków 1982), Filozofia dramatu (Paris 1990). W swej twórczości filozoficznej łączył elementy myśli augustyńskiej, fenomenologii, hermeneutyki, filozofii spotkania i aksjologii ${ }^{10}$. Był dobrym znawcą i kontynuatorem filozofii nowożytnej oraz współczesnej, zarazem zaś był w manifestowanej opozycji wobec filozofii arystotelesowsko-tomistycznej zarzucając jej: predylekcję do tworzenia zamkniętych na rozwój systemów, abstrakcyjność sformułowań, przenoszenie kategorii ogólnoontologicznych na świat człowieka itp. ${ }^{11}$.

Żywiołowa niechęć krakowskiego autora do tomizmu miała swoje reperkusje w zakresie problematyki Boga. Przyjmując prymat etyki przed metafizyką, tj. wtórność Logosu wobec Ethosu ${ }^{12}$, zrezygnował z racjonalno-dyskursywnych uzasadnień istnienia Boga. One go nie interesowały, nie sformułował również sprecyzowanych wobec nich zastrzeżeń. Był przekonany, że należy przyjąć priorytet ontologicznych rozważań możliwości związanych z ideą Boga przed metafizyką bytu absolutnego ${ }^{13}$. Właściwe rozumienie idei Boga było dla niego bardziej istotne aniżeli poszukiwanie Go w zewnętrznym świecie materialnym. Tischner zarzucał filozofii tomistycznej uprawianie mistyki istnienia, zbyt zawężone rozumienie doświadczenia człowieka, reizację Boga poprzez określanie Go terminami zaczerpniętymi ze świata materialnego: Pierwsza Przyczyna, Byt Konieczny, Akt istnienia, Pierwszy Poruszyciel. Traktowanie Boga jako ostatecznej racji wyjaśniającej zaistnienie kosmosu nie może zadowalać, gdyż pomija rolę człowieka na „scenie” świata.

Krakowski filozof kontynuował nurt myśli św. Augustyna, opowiadając się za filozofią podmiotu jako drogą ku Bogu ${ }^{14}$. Nie świat zewnętrzny, ale „wewnętrzny nauczyciel" może otworzyć człowieka na perspektywę Transcendencji. Filozofię podmiotu głosił Kartezjusz w swym „,cogito ergo sum”. Tischner wprowadził korekturę: „Jestem tym, dla k og o myślenie myśli”"15. Człowiek jest dla niego osobowym podmiotem, którego elementami są ,ja aksjologiczne" i ,ja agatologiczne”. Nie filozofia bytu, ale filozofia wartości jest właściwą drogą ku Bogu. W filozofii nowożytnej i współczesnej wyróżnione zostały trzy typy antropologii: nadziei P. Ricoeura i G. Marcela, wartości M. Schelera i filozofii człowieka otwartej na transcendentne Sacrum ${ }^{16}$.

Filozofia scholastyczna ograniczała doświadczenie człowieka do poznania empirycznego i świadomości własnego istnienia. Tischner postulował szerokie

${ }^{10}$ Por. W. Bonowicz, Tischner, Kraków 2001; J. Szmyd, Fenomen Tischnera, Krosno 1997.

11 Por. J. Tischner, Schyłek chrześcijaństwa tomistycznego, w: tenże, Myślenie według wartości, Kraków 1982, 205-227, 312-338.

12 Por. tenże, Myślenie według wartości, s. 260.

${ }_{13}$ Por, tamże, s. 267nn; tenże, Świat ludzkiej nadziei, Kraków 1975, 229-233.

14 Por. tenże, Myślenie wedtug wartości, s. 342-346.

15 Tamże, s. 346.

16 Por. tamże, s. 253. 
rozumienie doświadczenia ludzkiego, mianowicie uwzględnienie doświadczenia aksjologicznego związanego z takimi przeżyciami, jak: poszukiwanie nadziei, wiara, dobroć, cierpienie, społeczne interakcje $\mathrm{e}^{17}$. Specyficzną odmianą doświadczenia wartości jest przeżycie religijne, którego istotą jest idea Sacrum. Wiara jest naturalną potrzebą człowieka, ale warunkiem jej aktualizacji i dynamiki jest wejście człowieka w świat wartości. „Subiektywnym warunkiem możliwości religijnego myślenia jest Ja aksjologiczne"18. Stwierdzenie św. Augustyna, że ,wiara szuka zrozumienia”, inicjuje myślenie religijne. Język religijny odwołuje się do metafor i symboliki, pośrednio wskazując na niewyrażalność Bożej natury w sposób racjonalno-jednoznaczny. Religia jest dialogiem, a nie monologiem, jest wewnętrznym wezwaniem człowieka-pielgrzyma do wewnętrznej przemiany oraz doświadczenia nadziei i wolności poprzez absolutne Sacrum ${ }^{19}$.

Rezygnacja Tischnera $\mathrm{z}$ ontologiczno-metafizycznej drogi ku Bogu była powodem całkowitego braku zainteresowania drogami św. Tomasza ${ }^{20}$. W miejsce argumentacji kosmologicznej zaakceptował on dowód ontologiczny św. An= zelma, przypisując mu funkcję psychologiczno-terapeutyczną. Argument ten został zreinterpretowany w duchu filozofii podmiotu jako „czynnik psychologicznej perswazji” i „szukanie jakiegoś doświadczenia Boga”, dostrzeżenie nonsensowności w wypadku negacji Jego istnienia ${ }^{21}$. Krakowski autor optując za filozofią podmiotu i subiektywno-aksjologiczną filozofią Boga, był oskarżany przez zwolenników tomizmu egzystencjalnego o uleganie pokusie idealizmu ${ }^{22}$. Broniąc się przed takim zarzutem wyjaśniał, że subiektywność nie jest równoznaczna z subiektywizmem. Doświadczenie aksjologiczne jest indywidualnosubiektywne, lecz to nie podważa obiektywnego charakteru wartości ${ }^{23}$.

Tischner przyjmował jeszcze drugą możliwość dojścia do Boga, mianowicie poprzez odnalezienie Jego śladów w drugim człowieku. Była to droga wskazana przez francuskiego fenomenologa, Emmanuela Lévinasa. Twarz drugiego człowieka jest „otwartym horyzontem”, „nawiedzeniem Nieskończonego"24. Każdy człowiek doświadcza wolności, lecz wolność jest także odpowiedzialnością za innych ludzi. W tej perspektywie możliwe jest odkrycie obecności Boga. Filozofia Boga Józefa Tischnera jest kontynuacją filozofii podmiotu św. Augustyna, Kartezjusza, M. Schelera, E. Lévinasa, H. Bergsona, K. Jaspersa, całkowicie zaś przeciwstawna tomistycznej filozofii bytu.

17 Por. tamże, s. 341nn; tenże, Świat ludzkiej nadziei, s. 61-69.

18 Tenże, Myślenie według wartości, s. 347; por. tenże, Świat ludzkiej nadziei, s. 113-115.

19 Por. Myślenie według wartości, s. 114nn.

${ }^{20}$ Dowody te nazwał Tischner ,łudzącym balastem”, por. Świat ludzkiej nadziei, s. 242.

21 Por. tamże, s. 241-242.

22 Por. M. Gogacz, Btędna koncepcja Boga w heglizmie ks. Tischnera, „Emaus” 1992, nr 1, 17-20.

23 Por. Tischner, Myślenie według wartości, s. 267-271.

${ }^{24}$ Por. tamże, s. 183; tenże, Fillozofia dramatu, Paris 1990, 46-50. 
W nurt fenomenologiczno-egzystencjalny filozofii Boga włączył się także Karol Tarnowski, profesor krakowski, autor prac: Ku absolutnej ucieczce. Bóg i wiara w filozofii Gabriela Marcela (Kraków 1993), Człowiek $i$ Transcendencja (Kraków 1995). W dziejach ludzkiej myśli wyróżnił on dwie drogi prowadzące do Boga, które można określić skrótowo jako kosmologiczną i antropologicz$\mathrm{ną}^{25}$. Filozofia arystotelesowsko-tomistyczna odkrywa Boga jako Byt Konieczny i Pierwszą Przyczynę kosmosu; w tym typie racjonalno-dyskursywnej argumentacji człowiek jest traktowany jako byt jeden $z$ wielu. Krakowski autor nie dezawuował tej drogi do Boga, ale wskazał na jej epistemologiczne ograniczenia. Pojęcie Bytu Koniecznego jest sensowne, ujmuje bowiem jakiś aspekt Boga, ale jest to tylko pośrednie Jego ujęcie. Pojęcie takie jest tylko pojęciem, stanowiąc ,jedno z wielu i zawsze jedynie ludzkich, a więc skończonych i mizernych «okien» na Boga" 26 . Tego typu wypowiedzi nie są deklaratywnym agnostycyzmem epistemologicznym, ale zbliżają się do niego i przypominają subiektywizm Kanta.

Wielu myślicieli, na czele ze św. Tomaszem, uzasadniało istnienie Boga argumentem teleologicznym. Jego walor doceniał w pewnym stopniu nawet Dawid Hume, choć traktował go tylko jako interesującą hipotezę. Tarnowski ocenił krytycznie dowód z celowości, przyjmując możliwość naturalno-immanentnej eksplikacji genezy struktur celowych. Być może bowiem „rzeczy są jakie są jedynie dzięki wewnętrznym składnikiem wszechświata, które lepiej da się wyjaśnić naukowo"27. Przeciw argumentowi teleologicznemu może również przemawiać fakt zła, który trudno pogodzić z istnieniem Boga jako sprawczej przyczyny świata. J. H. Newman twierdził, że celowość nie dowodzi istnienia Boga, natomiast dopiero po uznaniu Jego realności można afirmować celowość świata. Podobne stanowisko zajął krakowski autor pisząc, że celowość „może wchodzić w skład przeżycia religijnego, ale nie da się jej po prostu udowodnić",28.

Krytyczna ocena argumentacji ontologiczno-kosmologicznej za istnieniem Boga, deklarowana w pismach K. Tarnowskiego, potwierdziła jego krytyczne stanowisko wobec filozofii arystotelesowsko-tomistycznej. Znalazł on inną drogę do Boga, biorąc za punkt wyjścia człowieka-zwłaszcza jego pragnienie absolutnych wartości, nieskończoności, poczucie tajemnicy. Przewodnikami na tej drodze byli dla Tarnowskiego: św. Augustyn, M. Scheler, M. Heidegger, G. Marcel, F. Ricoeur, E. Lévinas, M. Buber, P. Tillich. Nie filozofia bytu, ale filozofia człowieka jest właściwą drogą ku Bogu. O ile jednak św. Augustyn sformułował racjonalno-filozoficzny argument $\mathrm{z}$ prawdy potwierdzający nie-

${ }^{25}$ Por. K. Tarnowski, Ku absolutnej ucieczce. Bóg $i$ wiara w filozofii Gabriela Marcela, Kraków 1993, 281.

26 Tamże, s. 283.

27 Tenże, Źródło poznania Boga, ,Znak” 46 (1994) 59.

28 Tamże. 
odzowność istnienia Boga jako Prawdy Najwyższej, to autor pracy Człowiek $i$ Transcendencja zrezygnował z filozoficznych uzasadnień teizmu przyjmując za punkt wyjścia fakt religijnej wiary. Był przekonany, że nie jest moźliwa filozofia Boga jako autonomiczna dyscyplina, ponieważ filozofia chrześcijańska jest faktycznie inspirowana przez objawienie ${ }^{29}$. Idea Boga jako Bytu Koniecznego jest apriorycznie implikowana w doświadczeniu religijnym ${ }^{30}$. Ten typ ludzkiego doświadczenia jest intuicyjnym poznaniem Boga, rozpoznawalnym w wydarzeniach życia ludzkiego. Filozofia Boga wynika z logosu wiary, z doświadczenia religijnego, a nie $\mathrm{z}$ filozofii bytu.

Lévinas przyjmował w ludzkim życiu pra-obecność Absolutu, odkrywanie w skończoności człowieka-Nieskończoności-przynajmniej jako ideału. Tarnowski solidaryzował się z tym stanowiskiem, a także za Marcelem stwierdził, że w człowieku istnieje pragnienie Boga jako niewidzialnej Tajemnicy ${ }^{31}$. Doświadczenie religijne jest swoistym objawieniem Boga, którego obecność człowiek rozpoznaje w różny sposób: przez wielkość i piękno świata, twarz człowieka, wydarzenia życia. Dla Marcela Bóg jest tajemnicą, dla R. Guardiniego świętością, dla P. Ricoeura objawieniem boskości ${ }^{32}$. Wiara religijna jest dla człowieka wezwaniem do podjęcia odpowiedzialności za siebie i innych ludzi. Odpowiedzialność nie niszczy wolności, lecz nadaje jej głębszy sens aksjologiczny ${ }^{33}$.

Dokonany przez K. Tarnowskiego wybór antropologiczno-aksjologicznej drogi do Boga wynikał z przekonania, że jedynie taka droga respektuje w pełni podmiotowość i tajemnicę Boga. Ostatecznym słowem filozoficznej refleksji nad Bogiem jest teologia negatywna, milczenie wobec tajemnicy nieskończonego i niewidzialnego Boga $^{34}$. Filozofia, która opierając się na zasadzie racji dostatecznej mówi o Bogu jako Bycie Koniecznym, interpretuje jedynie prawdę uprzednio intuicyjnie rozpoznaną w doświadczeniu wiary.

Krakowski autor przyjął priorytet doświadczenia religijnego przed filozoficzną refleksją nad Bogiem, nie tylko w aspekcie psychologicznym (co z reguły jest faktem), lecz także w aspekcie metodologicznym. Jego stanowisko krytycznie zostało oceniane przez tomistów, którzy zarzucają mu kantowski agnostycyzm $^{35}$. Podważanie metodologicznej i merytorycznej autonomii filozofii wobec religii jest bliskie postawie fideizmu.

Wybitnym współczesnym kontynuatorem religijnej refleksji św. Augustyna był niemiecki myśliciel, Johannes Hessen (1889-1979), którym zainteresowali

${ }^{29}$ Por. tenże, Pytanie o filozofię chrześcijańską, „Znak” 42 (1990) 82-102, spec. 96 nn..

${ }^{30}$ Por. tenże, Źródto poznania Boga, s. 61.

${ }^{31}$ Por. tenże, Ku absolutnej ucieczce, s. 274.

32 Por. tamże, s. $276 \mathrm{nn}$.

33 Por. tamże, s. 279.

34 Por. tamże, s. 283.

35 Por. M. Gogacz, Podstawy odmian koncepcji Boga, „Studia Philosophiae Christianae” 27 (1991) nr 2, 10nn. 
się polsey autorzy. Jego platonizująę gnozeologię bardzo krytyeznie ocenił Hubert Mynarek ${ }^{36}$, natomiast jej wartości pozytywne w odniesieniu do problematyki filozofii Boga dostrzegł Alfons Nossol, profesor teologii w Katolickim Uniwersytecie Lubelskim i później arcybiskup Opola ${ }^{37}$. Ten ostatni poddał analizie tzw. intuicję totalitarną Hessena, będącą połączeniem intuicji intelektualnej, wolicjonalnej i emocjonalnej. Religijne poznanie Boga jest intuicyjnym supraracjonalnym aktem personalistycznym, różnym od poznania racjonalnodyskursywnego. Bóg jest uchwytny poznawczo przede wszystkim poprzez domenę wyższych wartości, które angażują całą osobowość człowieka, a nie tylko jego intelekt.

\author{
PHENOMENOLOGICAL-EXISTENTIAL TREND \\ IN POLISH CONTEMPORARY PHILOSOPHY OF GOD
}

(Summary)

The main followers of phenomenological-existential trend in the field of philosophy of God in Poland are: Marian Jaworski, Józef Tischner and Karol Tarnowski. Jaworski united thomistic arguments for existence of God with augustian philosophy of subject and personal-axiological experience. Tischner completely rejected thomism and his philosophy of God based on anthropology and personal values. Tarnowski also was critical toward ontological-cosmological arguments for existence of God. He is fallower of G. Marcel and therefore accepted religious faith as basis of theism.

${ }^{36}$ Por. H. Mynarek, Filozofia przeżycia religijnego w ujęciu Jana Hessena (Studium krytyczne), CT 28 (1957) 119-197; tenże, Johannes Hessens Philosophie des religiösen Erlebnisses, München 1963.

${ }^{37}$ Por. A. Nossol, „Cognitio Dei experimentalis”. Nauka Jana Hessena o religijnym poznaniu Boga, Warszawa 1974; S. Kowalczyk, Wieki o Bogu. Od presokratyków do teologii procesu, Wrocław 1986, 380-386. 